\title{
Tuotantoeläinten hyvinvointi - tuottajien asenteet ja käytännöt
}

\author{
Tiina Kauppinen ${ }^{1)}$, Annukka Vainio ${ }^{2)}$, Anna Valros ${ }^{1)}$, Kari Vesala ${ }^{2)}$ \\ ${ }^{1)}$ Helsingin yliopisto / Ruralia-instituutti, Lönnrotink. 3-5, 50100 MIKKELI \\ tiina.kauppinen@helsinki.fi,anna.valros@helsinki.fi \\ ${ }^{2)}$ Helsingin yliopisto / Sosiaalipsykologian laitos, Unioninkatu 37, 00014 HELSINGIN YLIOPISTO \\ annukka.vainio@helsinki.fi,kari.vesala@helsinki.fi
}

Miten kiinnostuneita suomalaiset tuottajat ovat tuotantoeläinten hyvinvoinnin edistämisestä? Mitä tuotantoeläinten hyvinvointi merkitsee eri tuottajille? Minkälaisia asenteita tuottajilla on tuotantoeläinten hyvinvointiteemaan liittyen? Mitkä asiat vaikuttavat tuottajien asenteisiin? Onko tuottajan mielestä eläinten hyvinvoinnilla yhteyttä tuotannon kannattavuuteen? Muun muassa näihin kysymyksiin pyrimme löytämään vastauksia tuotantoeläinten hyvinvointia ja tuottajien asenteita koskevassa tutkimuksessamme.

Tuottaja on avainasemassa eläimen hyvinvoinnin määräytymisessä eläin-ihmis-suhteen, toimintatapojen ja tuotantokäytäntöjen kautta. Tuottajien näkemykset vaikuttavat keskeisesti siihen, millaisia toimenpiteitä hyvinvoinnin lisäämiseksi ollaan valmiita tekemään ja kuinka paljon niihin halutaan investoida. Hoitajan asenne eläimiä kohtaan voi vaikuttaa hänen työmoraaliinsa, motivaatioon oppia uusia asioita sekä työstä koettuun tyytyväisyyteen. Nämä tekijät voivat puolestaan vaikuttaa hoitajan työsuoritukseen ja eläinten käsittelyyn (Hemsworth ym. 1989, 1994, 1999). Ihmisen ja eläimen välinen vuorovaikutus onkin merkittävä eläimen hyvinvointiin vaikuttava tekijä (Hemsworth \& Coleman 1998).

Laajempien jatkotutkimusten pohjaksi tehdyssä pilottitutkimuksessamme selvitimme tilakäyntien ja tuottajahaastatteluiden avulla, millaisia näkemyksiä suomalaisilla tuottajilla on tuotantoeläinten hyvinvoinnin parantamisesta. Myös tilakoon ja tuotantoratkaisujen vaikutuksia asenneilmastoon selvitettiin. Tuotantotilojen ja eläinten tarkastelun perusteella pyrittiin alustavasti selvittämään, toteutuvatko tuottajan näkemykset käytännössä eli heijastuuko tuottajan asenne hänen tapaansa hoitaa ja käsitellä eläimiään. Tarkastelussa huomioitiin kunkin tilan tilakoko, teknologiset ratkaisut sekä management. Asenteiden yhteyttä tuottajien toimintaan, eläinten hyvinvointiin ja tuottavuuteen tutkittiin käyttämällä mallieläiminä sikaa ja nautaa sekä mallitiloina porsastuotanto- ja lypsykarjatiloja. Alustavien tulosten perusteella tuottajien asenteista hahmottui erilaisia kannanottojen ja perustelujen kokonaisuuksia. Näkyvin ulottuvuus oli haastateltujen tuottajien suhtautuminen tuotantoeläinten hyvinvointiin "moralistisesti" (eläimen hyvinvointi on tuottajan työn päämäärä ja moraalinen itseisarvo) tai "utilitaristisesti" (eläinten hyvinvointi on väline, jonka avulla tuottaja saavuttaa muita päämääriä kuten rahaa tai esim. yleisemmin edistää omaa hyvinvointiaan).

Tutkimuksen tarkoituksena on saada lisää tietoa tuottajien asenteista koskien tuotantoeläinten hyvinvoinnin edistämistä. Tutkimalla, mitä yhteyksiä tuottajan asenteilla on eläinten hyvinvointiin, tuotostuloksiin ja tuotannon kannattavuuteen, voidaan entistä tehokkaammin motivoida tuottajia eläinten hyvinvoinnin parantamiseen. Tuottajien positiivinen asenne eläinten hyvinvoinnin edistämiseen parantaa myös tuotantosuunnan imagoa ja tuotteen eettistä laatua.

Asiasanat: tuotantoeläin, tuottaja, hyvinvointi, asenne, porsastuotantotila, lypsykarjatila 


\section{Johdanto}

Miten kiinnostuneita suomalaiset tuottajat ovat tuotantoeläinten hyvinvoinnin edistämisestä? Mitä tuotantoeläinten hyvinvointi merkitsee eri tuottajille? Minkälaisia asenteita tuottajilla on tuotantoeläinten hyvinvointiteemaan liittyen? Mitkä asiat vaikuttavat tuottajien asenteisiin? Onko tuottajan mielestä eläinten hyvinvoinnilla yhteyttä tuotannon kannattavuuteen? Muun muassa näihin kysymyksiin pyrimme löytämään vastauksia tuottajien asenteita koskevassa tutkimuksessamme. Tuotantoeläinten hyvinvointi on puhuttanut viimeaikoina niin alan asiantuntijoita, kuluttajia kuin kotieläintuottajiakin. Useita hyvinvointiin liittyviä epäkohtia on myös nostettu esiin tiedotusvälineissä, etenkin lihasikojen ja siipikarjan olosuhteet ovat olleet keskeisiä huolenaiheita. Elintarvikeketjun eri toimijoiden näkemykset eläinten hyvinvoinnista ovat erilaisia, mikä voi hankaloittaa yhteisen hyvän toimintaympäristön ja hoitokäytännön määrittelyä. Näkemyseroihin vaikuttavat toimijan tiedot ja kokemukset kotieläintuotannosta, asenteet sekä arvot.

Eläinten hyvinvointia määrittävät lainsäädäntö, elintarviketeollisuus sekä tutkijoiden ja kuluttajien vaatimukset. Tuottaja on kuitenkin avainasemassa eläimen hyvinvoinnin määräytymisessä eläin-ihmis-suhteen, toimintatapojen ja tuotantokäytäntöjen kautta. Tuottajien näkemykset vaikuttavat keskeisesti siihen, millaisia toimenpiteitä hyvinvoinnin lisäämiseksi ollaan valmiita tekemään ja kuinka paljon niihin halutaan investoida.

Hoitajan asenne eläimiä kohtaan voi vaikuttaa hänen työmoraaliinsa, motivaatioon oppia uusia asioita sekä työstä koettuun tyytyväisyyteen. Nämä tekijät voivat puolestaan vaikuttaa hoitajan työsuoritukseen ja eläinten käsittelyyn. Hoitajan asenteella ja käyttäytymisellä eläintä kohtaan on todettu olevan vaikutusta eläimen käyttäytymiseen, hyvinvointiin, terveyteen ja tuottavuuteen (Hemsworth ym. 1989, 1994, 1999). Ihmisen ja eläimen välinen vuorovaikutus onkin merkittävä eläimen hyvinvointiin vaikuttava tekijä. Jos hoitajan asenne esimerkiksi sikoja kohtaan on negatiivinen, sitoutuminen eläinten tarkkailuun ja puuttuminen tuotannon ja hyvinvoinnin ongelmakohtiin heikkenee (Hemsworth \& Coleman 1998). Hoitajan asenne vaikuttaa mm. siihen, miten usein hän käy katsomassa eläimiä, kuinka paljon käyttää aikaa eläinten tarkkailuun, miten käsittelee eläimiä hoitotoimenpiteiden aikana ja kuinka herkästi puuttuu epäkohtiin. Kaikki nämä tekijät vaikuttavat edelleen eläinten hyvinvointiin ja tuotantoon.

Tutkimuksen tarkoituksena on saada lisää tietoa tuottajien asenteista koskien tuotantoeläinten hyvinvoinnin edistämistä. Tutkimalla, mitä yhteyksiä tuottajan asenteilla on eläinten hyvinvointiin, tuotostuloksiin ja tuotannon kannattavuuteen, voidaan entistä tehokkaammin motivoida tuottajia eläinten hyvinvoinnin parantamiseen. Tuottajien positiivinen asenne eläinten hyvinvoinnin edistämiseen parantaa myös tuotantosuunnan imagoa ja tuotteen eettistä laatua.

\section{Aineisto ja menetelmät}

Laajempien jatkotutkimusten pohjaksi tehdyssä pilottitutkimuksessamme selvitimme tilakäyntien ja tuottajahaastatteluiden avulla, millaisia näkemyksiä suomalaisilla tuottajilla on tuotantoeläinten hyvinvoinnin parantamisesta. Myös tilakoon ja tuotantoratkaisujen vaikutuksia asenneilmastoon selvitettiin. Tuotantotilojen ja eläinten tarkastelun perusteella pyrittiin alustavasti selvittämään, toteutuvatko tuottajan näkemykset käytännössä eli heijastuuko tuottajan asenne hänen tapaansa hoitaa ja käsitellä eläimiään. Tarkastelussa huomioitiin kunkin tilan tilakoko, teknologiset ratkaisut sekä management. Asenteiden yhteyttä tuottajien toimintaan, eläinten hyvinvointiin ja tuottavuuteen tutkittiin käyttämällä mallieläiminä sikaa ja nautaa sekä mallitiloina porsastuotanto- ja lypsykarjatiloja. Tutkimusta jatketaan vuonna 2006 laajemmalla kvantitatiivisella kysely- ja galluptutkimuksella.

Mahdollisimman monipuolisen kuvan saamiseksi tutkimukseen pyrittiin saamaan mukaan yhdeksän sika- ja yhdeksän nautatilallista niin, että molemmista tuotantosuunnista on edustettuna kolme keskikokoista ja kolme suurta tilaa sekä kolme luomutilaa. Luomutilat olivat kooltaan keskikokoisia. Suurista sikatiloista yhtymiä oli kaksi, suurten nautatilojen joukossa taas oli yksi yhtymä. Tilat sijaitsivat eri puolilla Suomea.

Ennen varsinaisia tilakäyntejä suunniteltiin haastattelukysymykset tuottajille sekä lomake tuotantotilojen ja eläinten arvioimista varten. Haastattelukysymykset ja lomakkeen toimivuus testattiin etukäteen harjoitustilakäynneillä. Varsinaiset tilakäynnit tehtiin heinäkuussa 2005. Haastatteluissa selvitettiin erilaisten asenneväittämien avulla, mitä mieltä tuottajat ovat tuotantoeläinten hyvinvoinnin edistämisestä. Tuotantotilat ja -tavat kartoitettiin havainnoimalla ja kuvailemalla tuotantotilojen 
olosuhteita ja teknologisia ratkaisuja, tilalla käytettäviä eläinten hoitomenetelmiä sekä ruokinnan toteutusta. Lisäksi eläimiä tarkasteltiin silmämääräisesti ja seurattiin niiden aggressiivisuutta, pelokkuutta ja liikkumista.

Haastatteluosion analyysin menetelmänä käytettiin kvalitatiivisen haastattelututkimuksen menetelmää (Vesala \& Rantanen 1999), joka tutkii haastateltavien kannanottoja tutkijan esittämiin 10 väittämään. Tutkija analysoi 18 haastateltavan vastaukset yhteen väittämään kerrallaan. Aineisto luokiteltiin ensiksi kannanottoihin ja kannanottojen perusteluihin, minkä jälkeen etsittiin johdonmukaisuuksia näissä luokitteluissa. Haastattelukysymykset ja analyysi pohjautuvat Fishbeinin ja Ajzenin (Ajzen \& Madden 1986) tunnettuun asenneteoriaan, joka erittelee asenteessa (1) arvottavan kannanoton, (2) asenteen kohteen, (3) kannanottoa säätelevän normin ja (4) tulkitsijan oman arvion mahdollisuuksistaan vaikuttaa asenteen kohteeseen.

Eläimiä ja olosuhteita kuvailevan aineiston analysointia varten muokattiin A-tuottajien kehittelemän A-indeksin pohjalta pisteytysjärjestelmä, joka soveltuu nimenomaan tätä tutkimusta varten kerätylle aineistolle. Pisteytys tuo esille tilojen, tuotantosuuntien ja eri eläinryhmien (vasikat, hiehot, lypsylehmät jne.) välistä sekä yksittäisten muuttujien sisäistä hajontaa. Sovelletun indeksin pääpaino on olosuhteita mittaavissa muuttujissa. Pisteytyksen tulokset ovat suuntaa-antavia: niitä voidaan käyttää ainoastaan haastatteluaineiston rinnalla tutkimustilojen keskinäisen hyvinvoinnin arviointiin. Suppean pisteytysmenetelmän ja tutkimustilojen pienen määrän vuoksi tuloksia ei missään nimessä voida yleistää koskemaan muita kuin tutkimuksessa mukana olleita tiloja.

\section{Alustavia tuloksia}

Toistaiseksi haastattelu- ja hyvinvointiarvioaineistojen erillinen analysointi on vielä kesken eikä aineistoja ole päästy tarkastelemaan kokonaisuutena. Erillisistä aineistoista on kuitenkin saatu muutamia alustavia tuloksia, joiden pohjalta tarkastelua jatketaan ja tarkennetaan.

Eläimiä ja olosuhteita kuvailevan aineiston analysoinnissa pistemääriä tarkasteltiin suhteessa tuotantosuuntaan (sika / nauta), tilatyyppiin (suuri / keskikokoinen / luomu) sekä eri eläinryhmiin (porsitus / välikasvatus / joutilaat; pikkuvasikat / teinivasikat / lypsylehmät). Pisteitä kertyi eri eläinryhmille samankokoisilla tiloilla keskimäärin saman verran. Ryhmien sisällä esiintyy kuitenkin huomattavaa vaihtelua, kun tilatyypin merkitystä ei oteta huomioon. Tarkasteltaessa pistemääriä sekä tilatyypin että eläinryhmien mukaan vaihtelu tulee selvimmin esille: eri tilojen välillä on siis eroja arvioidussa hyvinvoinnin tasossa. Myös tilojen sisällä on vaihtelua eri eläinryhmien olosuhteissa. Jatkossa tullaan tarkastelemaan pistemääriä suhteessa muihin luokitteleviin muuttujiin (esimerkiksi pihatto- vai parsinavetta) ja vertailemaan tuloksia haastattelumateriaalin tulosten kanssa.

Tuottajien kvalitatiivisen asennehaastattelun alustavan analyysin perusteella tuottajien asenteista hahmottui erilaisia kannanottojen ja perustelujen kokonaisuuksia. Tuottajien mielestä eläinten hyvinvoinnin edistäminen on tärkeää eläinten itsensä takia. Tuottajat yleisesti liittivät myös yhteen eläinten hyvinvoinnin edistämisen ja eläinten tuottavuuden: hyvinvoiva eläin tuottaa rahaa, se on tuottajan elinkeino. Useimmat tuottajat myös kokivat, että heidän oma hyvinvointinsa ja eläinten hyvinvointi ovat riippuvaisia toisistaan. Jotkut tuottajat olivat myös päinvastaista mieltä: eläinten hyvinvointia edistetään tuottajan oman jaksamisen kustannuksella. Tuottajat asettivat eläinten hyvinvoinnin edistämiselle myös rajoja: hyvinvoinnin edistäminen voi joissakin tapauksissa mennä liian pitkälle, sillä eläimet ovat heidän mielestään tyytyväisiä myös vaatimattomampiin olosuhteisiin.

Suurin osa tuottajista oli sitä mieltä, että eläinten hyvinvoinnin edistäminen ei ole riippuvaista tuotantotavasta: monenlaisilla ratkaisuilla voidaan päästä hyvään tulokseen. Tuottajat suhtautuivat peruspositiivisesti uuteen teknologiaan: he näkivät sen hyvänä apuvälineenä, joka myös helpottaa hoitajan työtä. He kuitenkin korostivat, että hoitotyön tekee ihminen eikä kone. Oli myös tuottajia, jotka suhtautuivat epäluuloisesti uuteen teknologiaan; se oli heidän mielestään epäluotettavaa eikä se poistanut inhimillisen erehdyksen riskejä. Arveltiin myös, että jotkut tuottajat käyttivät uutta teknologiaa arveluttavalla tavalla.

Luomutuotanto eläinten hyvinvoinnin edistäjänä jakoi tuottajien mielipiteet. Oli niitä, jotka olivat vakuuttuneita siitä, että luomun tiukempien säännösten takia luomutuotantotiloilla eläimet oikeasti voivat keskimääräisesti paremmin kuin muiden tuotantoalojen tiloilla. Monet eiluomutilalliset kuitenkin arvelivat, että luomussa harjoitettavat hoitokäytännöt itse asiassa huonontavat eläinten hyvinvointia. Epäiltiin, että luomussa eläinten lääkitys ei toimi ja että siinä on ruokinnallisia epäkohtia, luomun ympärivuotinen ulkoilusääntö on eläinten kannalta epämiellyttävää ja että 
luonnonmukainen poikiminen aiheuttaa kärsimystä eläimelle. Esitettiin myös arveluja, että jotkut tuottajat ovat siirtyneet luomuun taloudellisten etujen eikä eläinten hyvinvoinnin edistämisen vuoksi.

Haastattelusta etsittiin myös suuria, yli haastattelukysymysten ja yli yksittäisten haastateltavien kaartuvia ulottuvuuksia. Kaikkein näkyvin ulottuvuus oli haastateltujen tuottajien (1) suhtautuminen tuotantoeläinten hyvinvointiin "moralistisesti" (eläimen hyvinvointi on tuottajan työn päämäärä ja moraalinen itseisarvo) tai "utilitaristisesti" (eläinten hyvinvointi on väline, jonka avulla tuottaja saavuttaa muita päämääriä kuten rahaa tai esimerkiksi yleisemmin edistää omaa hyvinvointiaan). Toinen ulottuvuus liittyi itse tuotantoeläinten hyvinvoinnin määritelmään: (2) Onko tuotantoeläinten hyvinvointi sama asia kuin niiden tuottavuus vai onko niiden hyvinvointi muutakin kuin tuotantoluvut? Myös kolmas ulottuvuus liittyi edellä mainittuihin ulottuvuuksiin: (3) onko tuotantoeläinten hyvinvoinnin edistäminen tuottajien mielestä harmoniassa vai ristiriidassa tuottajan hyvinvoinnin ja etujen kanssa? Neljäs ulottuvuus liittyi tuottajien arviointiin omista toimintamahdollisuuksistaan: (4) missä määrin tuottaja voi itse vaikuttaa tuotantoeläinten hyvinvointiin, ja missä määrin tuotantoeläinten hyvinvointi on tuottajan vaikutusvallan ulottumattomissa olevista tekijöistä riippuvaa?

Nämä ulottuvuudet olivat erittäin kontekstuaalisia ja suhteellisia: samalle tuottajalle ulottuvuuden yksi ääripää saattoi olla käytössä tietyssä tilanteessa ja toinen ääripää toisessa tilanteessa. Ulottuvuuksien ääripäät eivät myöskään sulkeneet toisiaan pois, toisin sanoen sama tuottaja saattoi suhtautua tuotantoeläinten hyvinvointiin sekä moralistisesti että utilitaristisesti. Sama tuottaja saattoi määritellä, että tuottaja on uupuessaan itse päävastuussa eläintensä hyvinvoinnista, mutta samalla valittaa sitä, että kilpailuyhteiskunta tuo tuottajille paineita laskea tuotteiden hintaa.

\section{Johtopäätökset}

Johtopäätöksiä tuottajien asenteiden ja eläinten hyvinvoinnin yhteyksistä ei tutkimuksen tässä vaiheessa vielä voida vetää. Hyvinkin erilaisten tilojen tuottajilla saattoi olla keskenään samanlaisia asenteita, ja vastaavasti tuottajien eriävät mielipiteet eivät sulkeneet pois samansuuntaisia hyvinvointiarvion tuloksia eri tiloilla. Aineiston lopullisen analyysin jälkeen tämän pilottitutkimuksen pohjalta tehdään laajempi kvantitatiivinen tuottajien asenteita ja tuotostuloksia mittaava ja yhdistävä tutkimus, jonka odotetaan olevan laajemmin yleistettävissä koskemaan suomalaisia kotieläintiloja ja eri tuotantosuuntia.

\section{Kirjallisuus}

Ajzen, I \& Madden, T.J. 1986. Prediction of Goal-Directed Behavior: Attitudes, Intentios, and Perceived Control. Journal of Experimental Social Psychology 22:453-474.

Hemsworth, P. H., Barnett, J. L., Coleman, G. J. \& Hansen, C. 1989. A study of the relationships between the attitudinal and behavioural profiles of stockpeople and the level of fear of humans and reproductive performance of commercial pigs. Applied Animal Behaviour Science 23: 310-314.

Hemsworth, P. H., Coleman, G. J. \& Barnett, J. L. 1994. Improving the attitude and behaviour of stockpeople towards pigs and the consequences on the behaviour and reproductive performance of commercial pigs. Applied Animal Behaviour Science 39: 349-362.

Hemsworth, P. H. \& Coleman, G. J. 1998. Human-livestock interactions: the stockperson and the productivity and welfare of intensively farmed animals. Cab International, Wallingford.

Hemsworth, P. H., Pedersen, V., Cox, M., Cronin, G. M. \& Coleman, G. J. 1999. A note on the relationship between the behavioural response of lactating sows to humans and the survival of their piglets. Applied Animal Behaviour Science 65: 43-52.

Vesala, K.M. \& Rantanen, T. 1999. Pelkkä puhe ei riitä. Maanviljelijän yrittäjäidentiteetin rakentumisen sosiaalipsykologisia ehtoja. Yliopistopaino, Helsinki. 